Cómo citar este trabajo: Riesco Chueca, P. (2020). From place theory to landscape theory: non-place, distality and character. Boletín de la Asociación de Geógrafos Españoles, 85, 2858, 1-36. https://doi.org/10.21138/bage.2858

\title{
De la teoría del lugar a la teoría del paisaje: no-lugar, distalidad y carácter
}

From place theory to landscape theory: non-place, distality and character

\author{
Pascual Riesco Chueca \\ riescochueca@us.es \\ Centro de Estudios Paisaje y Territorio \\ Universidad de Sevilla (España)
}

\section{Resumen}

Se intenta situar conceptualmente el lugar y su contrafigura, el no-lugar, en el marco de la teoría del paisaje. Para ello se comparan los atributos que han venido aplicándose a la noción de lugar con las dos dimensiones, apego e interacción, que sustentan nuestra matriz clasificatoria del paisaje. Dicha matriz, libremente inspirada en la teoría cultural "grid-group", distingue cuatro tipos de paisaje. Un objeto del presente artículo es aclarar la posible ubicación de lugar y nolugar dentro de la citada matriz. La discusión consiguiente muestra que tanto la clasificación como el propio concepto de paisaje encuentran en las dinámicas de lo contemporáneo un potente vector desestabilizador, que derrite los límites entre tipos, crea disrupción entre los atributos del paisaje y problematiza el concepto de carácter paisajístico.

Palabras clave: no-lugar; paisaje; lo distal; apego; interacción social.

\begin{abstract}
An attempt is made at locating place and its counter-figure, non-place, within the framework of landscape theory. To do so, we compare the attributes that have been applied to the notion of place with two dimensions (attachment and interaction), used in our landscape classification
\end{abstract}


matrix. This matrix, freely inspired by the grid-group cultural theory, separates four landscape types. Our main object is to clarify the status of place and non-place within the landscape matrix. The ensuing discussion shows that both the classification and the landscape concept itself are exposed to hyper-modernization, a powerful destabilizing vector that melts the boundaries between types, creates disjunction between landscape features, and problematizes the concept of landscape character.

Key words: non-place; landscape; distality; place attachment; social interplay.

\section{Introducción}

La discusión sobre el concepto de lugar ha estado abonada por copiosos caudales de reflexión. Con sus rasgos reconocibles, su toponimia, sus valores y sus memorias, los lugares constituyen centros de significación paisajística; la vieja discusión al respecto recapitula el dipolo civilizaciónbarbarie. Es conocida la aportación de Heidegger a la teoría del lugar. Una célebre cita menciona que la tarea de estructurar espacio es, en esencia, la de despejar lugares ("Freigabe von Orten": Heidegger, 2002, pp. 206-207). ${ }^{1}$ En esta intuición palpitan recuerdos de la primigenia selva germánica, que solo se hacía habitable en la medida en que se abrían calveros compatibles con el habitar. La tarea civilizatoria se iniciaba abriendo rozas, que aclaraban lo impenetrable y ponían al habitante en un eje vertical, en comunicación con los astros y con un impalpable fundamento, raíz o patria; en el cruce de tierra y cielo, mortales y divinos, allí se hacía posible el ejercicio, inherentemente poético, del habitar. Heidegger, sin embargo, dejaba planteada desde el primer momento la incertidumbre inherente a esta tarea de despeje: en tales sitios aclarados, el destino de los habitantes tanto puede dirigirse hacia lo salvífico, un hogarpatria, como a su opuesto, el desterramiento, o a errar por la indiferencia ante ambas opciones; tanto puede engendrar lugares sacros como espacios vaciados.

Este proceso generador de lugares es esencialmente ambivalente. Así lo testimonian reacciones tempranas al movimiento moderno, que, con su potencia tecnológica, radicaliza el vaciamiento; un vaciamiento entendible por algunos como demolición, por otros, como apertura a lo nuevo. La metáfora heideggeriana, un claro desbrozado en la espesura, que permite instalar en él un lugar pleno o iniciar un proceso de arrasamiento, contiene en sí misma la potencia dual de lo que Schumpeter denominaba "destrucción creativa", motor destacadísimo de las dinámicas

1 Todas las traducciones y glosas de textos originales son del autor, salvo cuando se cita expresamente una referencia bibliográfica previamente traducida. 
liberales. Si el calvero hospitalario, abierto mediante rozas en la densa maraña boscosa, evoca los atributos de la vida buena, en su extensión y crecimiento indiscriminado acecha el peligro de la tabla rasa; en los excesos de control vive otro peligro no menor, el de enfundar el espacio en una camisa de fuerza y sofocarlo a base de vigilancia. Karl Kraus tildaba a un pionero del movimiento moderno, Adolf Loos, de "arquitecto de la tabla rasa"; y el crítico Ludwig Hevesi bautizó con sorna "Café Nihilismus" a una de las obras más depuradas de Loos, el Café Museum (1898) (Cacciari, 2002, p. 24).

Categorías ominosas, pues, como la tabla rasa, el vaciamiento, el espacio totalitario o el nolugar, aletean en torno a los nuevos paisajes creados por la Modernidad. El habitar es un proceso rico, que teje vínculos y sostiene miradas, pero su eclosión exitosa, que a tenor de las imágenes empleadas por Heidegger contiene rasgos contemplativos y artesanales, puede verse abortada por los rápidos y potentes metabolismos de lo contemporáneo, o envenenada por concepciones mágico-esencialistas y excluyentes. ${ }^{2} \mathrm{Ha}$ interesado a numerosos autores inventariar los trazos principales que acompañan al lugar en sentido antropológico, algo que puede parafrasearse como el buen lugar, el lugar en su sentido pleno. La riqueza teórica desplegada en este afán es otra selva impenetrable, con numerosas palabras clave -sentido del lugar, "genius loci", alma, fisonomía, semblante, autenticidad, carácter: véase una útil discusión en Jiven y Larkham (2003)-, ${ }^{3}$ pero se detectan ciertas coincidencias.

Gyerin (2000, pp. 464-465) planteaba tres ingredientes implícitos al concepto de lugar: una ubicación geográfica, finita en su extensión, aunque de bordes elásticos; ${ }^{4}$ una forma material, un ensamblaje de objetos naturales o artificiales; y una carga de significados y valores, resultado de procesos de interpretación, narración, percepción, sentimiento, comprensión e imaginación. Escobar (2001, p. 140) proporciona una definición variante, también escueta, según la cual un lugar es algo importante en la vida de la mayor parte de las personas y ofrece tres campos de experiencia: arraigo (aunque inestable), conciencia de límites (aunque permeables) y conexión con la vida cotidiana (aunque su identidad sea algo construido, atravesado por el poder y nunca definitivo). Esta fórmula de mínimos - arraigo, límites, cotidianidad-puede adornarse con otros

2 Leach (1998) analiza en un texto titulado "El lado oscuro del domus" el cariz siniestro que adquiere la obsesión nativista en ciertas ramificaciones de la teoría espacial de Heidegger.

3 Gallardo Frías (2012) pasa revista a numerosas teorizaciones que, con muy dispar terminología y método, se acercan a la cuestión.

4 Sobre la estrecha dependencia y mutualidad entre los conceptos de ciudad y borde urbano, véase Ipsen (2006, pp. 115-133). 
atributos secundarios si se pasa a caracterizar el buen lugar, aquel que ofrece condiciones para enriquecer la vida y la sociedad de las personas a él ligadas. Con esta intención, Augé (1992, p. 74) desarrolla el concepto de lugar antropológico, describiendo tres formas elementales del espacio socializado: la línea, la intersección de líneas y el punto de intersección; sobre estas geometrías se instalan los atributos de lo histórico (permanencia), relacional (interacción) e identitario (define un nosotros).

Por nuestra parte, podríamos sintetizar los rasgos del buen lugar: un espacio exitoso y rico en relación, percibido como un nudo y fragmento singular con el que se identifican sus residentes o transeúntes; en él o en torno a él florece la actividad humana; la historia tiene margen para sedimentar con sus numerosas capas de significación y matices; las relaciones sociales se entrelazan mediante tramas inequívocamente espaciales, aprovechando los valores formales disponibles. El lugar traba un nodo de mediación entre lo global y la experiencia personal, como precisa Nogué (2018, p. 241) sobre la base del ya clásico estudio de Tuan (1977) acerca de la polaridad espacio-lugar. Heise (2008), al explorar este dipolo, concibe una imaginación ambiental que anuda el sentido del lugar con el sentido del planeta.

Indudablemente, es necesario tomar precauciones para no diluir el discurso en loas acríticas, que atribuyen al lugar una inmediata reconocibilidad y ocultan potenciales problemas. Es útil por ello útil la advertencia de Kolb (2008, p. 28) sobre los riesgos de enfatizar nociones como centralidad y unidad a la hora de caracterizar lo propio del lugar: "identifying real places with centered, hierarchical locales for unified communities applies overly rigid concepts to our world".

Se erige en las antípodas de lugar el término no-lugar, acuñación propuesta inicialmente por Webber (1964), pero reelaborada, en el seno de un nuevo marco teórico, por Marc Augé. ${ }^{5}$ Para este, el término alude a espacios dominados por el gobierno de la movilidad, ricos en elementos intercambiables o mostrencos, con los que no es fácil establecer una relación espacial demorada ni singularizada. Como se ha indicado, Augé reconoce como atributos del lugar

5 El planteamiento de Webber es interesante: más que un afán de cohabitar o compartir espacios labrados en común, la nueva ciudad expresa la primacía de la libre movilidad, la caprichosa e instantánea accesibilidad de experiencias dispersas. La prioridad reside en "the accessibility rather than the propinquity aspect": la accesibilidad más que la propincuidad; estar conectado a las infraestructuras de movilidad, no vivir cerca de otros. Augé no parece sentir ninguna deuda hacia Webber. De hecho, como ocurre a menudo en obras clásicas de teoría francesa, la bibliografía prescinde de autores no francófonos. 
antropológico su condición identitaria, relacional e histórica, ${ }^{6}$ afirmando en consecuencia: "un espacio que no puede definirse ni como identitario, ni como relacional, ni como histórico, se manifestará como un no-lugar". 7 Según ello, un no-lugar no es aquel que carece de solamente una o dos dimensiones: es precisa la simultánea ausencia de las tres. A ello se añade un ingrediente adicional, que a menudo es pasado por alto: el no-lugar es para Augé un espacio presidido por el control de los accesos y las circulaciones. La definición imperiosa de los modos de tránsito, transporte, recorridos (en estructuras de ocio) o estacionamiento, son factores que impiden al espacio florecer. Entre los ejemplos desarrollados por Augé se encuentran el campo de refugiados, los corredores de circulación de personas y bienes (vías rápidas, intercambiadores, estaciones, aeropuertos) y los propios vehículos (1992, p. 44). Si el lugar antropológico crea lo orgánicamente social, los no-lugares son contractuales y producen soledad; los individuos interaccionan, no con otros individuos, sino con textos reguladores, cuyos proponentes son entidades morales o instituciones (pp. 120-121).

Existe un importante antecedente, que Augé tampoco cita, en la obra de Carl Schmitt. Allí se vincula de modo explícito la intensa movilidad contemporánea con la extinción del lugar, un proceso para el que usa el término "Entortung" (deslocalización, vaciamiento, evisceración): "la general expansión hacia la libertad, una abolición del sentido tradicional del lugar y, en este sentido, una movilización total, del grado más intensivo, una generalizada deslocalización, que sacó de quicio al mundo eurocéntrico". ${ }^{8}$

El no-lugar se caracteriza por tres ausencias - no proporciona espacio para el encuentro; no constituye una referencia compartida para un grupo; no tiene entronque histórico-; pero, sobre este vaciamiento inicial se instala el diseño más controlador. Es un diseño que, citando y manipulando referencias a los lugares tradicionales, pasa a gobernar el flujo y remanso de masas nutridas: el modo principal de inserción en él es un contrato anónimo. En el concepto de nolugar resuenan ecos de la heterotopía de Foucault: "a modo de contra-ubicaciones, a modo de utopías realizadas de hecho, en las cuales las ubicaciones reales, todas las otras ubicaciones

6 O, como se parafrasea a sí mismo el propio autor, años después: un lugar antropológico es un espacio en que pueden leerse inscripciones del vínculo social (por ejemplo, reglas de residencia impuestas a todos) y de la historia colectiva (por ejemplo, lugares de culto) (Augé, 2010, p. 172).

7 "[C]ar un espace qui ne peut se définir ni comme identitaire, ni comme relationnel, ni comme historique définira un non-lieu" (Augé, 1992, p. 100).

8 "Die allgemeine Bewegung zur Freiheit, eine Aufhebung traditionaller Ortungen und in diesem Sinne eine totale Mobilmachung intensivster Art, eine allgemeine Entortung, hob die europazentrische Welt aus den Angeln" (Schmitt 1950, p. 210). Véase el comentario a este pasaje en Cacciari (2002, p. 44) 
reales que se dan en el seno de la cultura están a la vez representadas, puestas en cuestión e invertidas; a modo de lugares que están fuera de todos los lugares, aunque sean efectivamente localizables". 9

Aunque el autor y sus seguidores se han distanciado de una interpretación directamente condenatoria o peyorativa de los no-lugares, es inevitable percibir en la propia definición del concepto una condena implícita, evidentemente extensiva a la sociedad que los genera. El modelo teórico de Augé se resiente de su organización original, vertebrada sobre el dipolo lugar / no-lugar. La dicotomía tiene de por sí proclividades a acumular elogios sobre un polo (lugar) y dicterios sobre el opuesto (no-lugar); ello a pesar de la insistencia del autor en describirlos como polaridades en eterna fuga (1992, p. 101): ni el lugar termina nunca de cuajar, ni el no-lugar llega a estabilizarse. ${ }^{10}$ Surge la paradoja de que ciertos ámbitos, que Augé sitúa sin titubeos en la categoría de no-lugares, gozan de alta estima entre los más jóvenes, que despliegan gran parte de su vida social y de relación en sus entrañas. Es el caso de las grandes superficies comerciales, donde muchos adolescentes encuentran un espacio de sociabilidad privilegiado. No escasean, en efecto, los estudios sobre preferencias paisajísticas que sitúan en un lugar destacado estos espacios de consumo indiscriminado, carentes en general de signos locales (Lazzari, 2012; García Martín, 2013). Por otra parte, el propio Augé (2010, p. 176) describe, en una revisión posterior del concepto, una percepción que se abre paso, esperanzada y abierta a la utopía: el no-lugar como espacio de plasticidad y creación, donde el diseño arquitectónico y urbanístico alcanza su máximo grado de libertad.

Es importante destacar que la popularización del término no-lugar ha llevado, abusivamente, a aplicarlo a muchos paisajes que no contienen los rasgos definitorios expuestos por Augé. Una desviación frecuente procede de incluir en dicha rúbrica paisajes que sería más apropiado denominar distales, como muestran algunos ejemplos. En el caso de Brodgen (2016), se estudian diversos espacios degradados, solares y descampados en un ensayo dedicado a la fotografía y el no-lugar. Otra aplicación abusiva del término no-lugar se produce cuando se extiende a cualquier espacio que no puede considerarse lugar en sentido pleno; es decir se define el no-lugar como el simple negativo o complementario del concepto lugar. Así parece

9 "Des sortes de contre-emplacements, sortes d'utopies effectivement réalisées dans lesquelles les emplacements réels, tous les autres emplacements réels que l'on peut trouver à l'intérieur de la culture sont à la fois représentés, contestés et inversés, des sortes de lieux qui sont hors de tous les lieux, bien que pourtant ils soient effectivement localisables" (Foucault, 2004, p. 15).

10 El dipolo lugar / no-lugar es un instrumento de medida del grado de socialización y simbolización de un determinado espacio (Augé, 2010, p. 172). 
ocurrir en el libro editado por Peillon y Corcoran (2004) sobre los paisajes de Irlanda. En otros casos, han sido tratados como no-lugares ciertos espacios de suma banalidad, parajes mostrencos, sin rostro, dominados por piezas de equipamiento seriado (mobiliario, publicidad, cerramiento, muros de contención, naves). La acumulación de prefabricados es sin duda atentatoria y mina gravemente el sentido del lugar, pero no conduce por fuerza al no-lugar teorizado por Augé.

Parece pues evidente que limitar la atención a lugares y no-lugares reduce la perspectiva a dos extremos y que es necesario encuadrar todo ello en el marco de un concepto amplio y útil, el de paisaje. Las secciones siguientes se consagran a esa tarea.

\section{Una clasificación social de los paisajes, sobre dos coordenadas}

Son pocas las clasificaciones del paisaje derivadas no de su materialidad y estructura, sino de los patrones de convivencia, afectos y relaciones que provocan; la práctica más consolidada se basa en una descripción cuidadosa del territorio, lo que lleva a identificar paisajes, separando distintos ámbitos homogéneos: véase por ejemplo una reciente identificación de paisajes agrarios en España (Molinero, Ojeda \& Tort, 2011). Ciertamente, la caracterización y, en general, la reflexión sobre lugar y paisaje viene emancipándose de la estricta obediencia a un inventario material. Paasi (1991, p. 249) alude al lugar como un "situated episode of life history [...], real, imagined, or utopian"; desligándolo con ello de una precisa escala y de hechos objetivables de orden material.

La nueva reflexión sobre el espacio introduce por lo tanto ingredientes discursivos, emocionales e identitarios que tienden a desmaterializar las bases teóricas. En una publicación anterior (Riesco Chueca, 2011, p. 70) se revisa el concepto de paisaje a la luz de algunas predilecciones contemporáneas, vinculadas a "los juegos de lenguaje y a la construcción de discurso"; enfoques que "insiste[n] en la alteridad y la diferencia". Pero precisamente por su énfasis en lo simbólico-discursivo o en lo interactivo-coreográfico, la correspondiente teoría presta escasa atención a la tipificación de paisajes. Ni las "geografías emocionales" (Luna \& Valverde, 2015), ni la corriente llamada "non-representational theory" dan prioridad a la clasificación, una de las tareas demandadas por el Convenio Europeo del Paisaje. Entre los no-representacionales, el eje no es discursivo, ideológico ni simbólico, sino que se centra en la acción y la interacción; estas teorías "locate the making of meaning and signification in the 'manifold of actions and interactions' rather than in a supplementary dimension such as that of discourse, ideology or 
symbolic order" (Anderson \& Harrison, 2010, p. 2). Un autor como Tilley (1994), en su encuadre fenomenológico del paisaje, se abstiene de cualquier intento clasificatorio.

En contribuciones anteriores (Riesco Chueca, 2003, p. 60; Gómez Zotano \& Riesco Chueca, 2011, p. 154) se propuso una clasificación, aplicable a paisajes no urbanos, que pretendía ensanchar la perspectiva introduciendo dos ejes de contemplación, ambos originados en la sociedad que despliega redes de relación y aprecio en torno a los lugares. Por un lado, la capacidad configuradora o tejedora de interacción social suscitada por un paisaje; por otro, la apreciación y el grado de atracción, vinculación o identificación experimentado hacia dicho paisaje.

Este esquema en dos ejes, implícito pero no desarrollado en la primera publicación, de 2003, se inspiraba en la matriz clasificatoria de la llamada "grid-group cultural theory" (cuyos principales iniciadores fueron Mary Douglas, Michael Thompson y Aaron Wildavsky; véase en Mamadouh, 1999; Douglas, 2005), un modelo teórico para el que no existe traducción consensuada al español. ${ }^{11}$ Con el tiempo, el esquema ha experimentado modificaciones intensas a manos de sus propios originadores (Spickard, 1989), pero pueden esbozarse algunos trazos dominantes de la teoría. "Group" sugiere la capacidad de forjar lazos integradores, que invitan a la incorporación y la pertenencia; "grid", el efecto de un control más abstracto, basado en normas y clasificaciones asumidas que regulan comportamientos, reparten tareas y fijan posiciones, como en las barras de una parrilla. Ambas dimensiones ejercen control social: "group", a través de la presión de grupo, basada en un sentido de pertenencia y miedo a la exclusión; "grid", mediante el acatamiento de normas, campos de especialización y límites, así como miedo a la sanción. La teoría "grid-group" ha sido extensamente aplicada, y a veces ha servido de bastidor para el estudio espacial. La propia Douglas (2011, p. 214) aplicó los ejes "grid-group" para caracterizar cuatro tendencias en cuanto a orden espacial y papel asignado a los monumentos. Moore (2004) adaptó la misma matriz en una indagación sobre la base social de ciertos espacios rituales o sacros en las culturas andinas.

Era inherente al esquema paisajístico propuesto en 2003 y ampliado en 2011 la adopción de dos dimensiones o ejes. El primero expresa la atracción, la seducción, la identificación con el

11 Algunos autores han usado la traducción red-grupo, aunque red evoca conexiones flexibles, alejándose de lo que pretende sugerir "grid". Una traducción polisílaba parece casi inevitable en lengua romance. Anyó Sayol (2008, p. 153) propone estructura-incorporación. 
paisaje (apego, "attachment"). ${ }^{12}$ Esta variable es bien conocida por estudios como los realizados por Altman y Low (1992), que inventariaban vías generadoras de apego a un lugar ("place attachment"): vínculos hereditarios (antepasados, herencias); lazos económicos (titularidad del terreno, ocupación profesional en él); movilización por pérdida o deterioro de un lugar; relación espiritual o mitológica con el lugar; actividad ritual o cultural; relatos (leyendas, toponimia, oralidad en general). El otro eje (interacción, "interplay") enlaza con las teorías norepresentacionales antes citadas; describe la intensidad de interacción, la densidad de intercambios, relaciones y rutinas sustentadas por un espacio. Se acerca al concepto de lo relacional usado por Augé (1992, pp. 67-71): el lugar inscribe espacialmente configuraciones personales (dicho de otro modo, borda constelaciones sobre el lienzo espacial). He renunciado a identificar este eje con el "group" de la teoría cultural, puesto que la densa interacción y las mallas relacionales no exigen sensación de pertenencia. En algunos casos sí aparecerán los rasgos del grupo (como en las viejas comunidades campesinas), ${ }^{13}$ pero en otros, la interacción está sustentada por fuerzas de mercado y estructuras contractuales.

Ambas dimensiones tienen su razón de ser paisajística: expresan acciones y afectos de índole o repercusión espacial, que aumentan la resiliencia del paisaje. El apego lleva a hacer lecturas, a fundar oralidad y por lo tanto a erigir un plano de imágenes y textos sobre la materialidad del paisaje. La densidad de relación, la interacción, equivale a un conjunto de prácticas espaciales que tejen configuraciones entre personas, situando e inscribiendo una parte de su vida en el paisaje. Un paisaje que posee valores altos de ambas dimensiones (mucho apego, mucha interacción) es doblemente importante en la vida de sus poblaciones.

Con arreglo a dicha clasificación en dos ejes, atracción-interacción ("attachment-interplay"), los cuatro tipos resultantes, para paisajes no urbanos (Riesco Chueca, 2003, p. 60), eran los siguientes (Figura 1):

[a] Si un paisaje cotiza alto en atracción e interacción, es decir, si suscita apego y valoración, al tiempo que configura relaciones entre personas, es por lo general un paisaje tradicional campesino, tipo relicto que se encuentra en rápida extinción.

12 Por preservar la cercanía fonética a la dimensión "grid", cabría usar en inglés la voz "grip", en su acepción de fascinar, atrapar: doble referencia a la seducción de un paisaje capaz de generar apego y deseo de identificación. Pero es preferible, como se indica seguidamente, sustituir también la otra dimensión, "group", por una variable menos cargada de connotaciones de pertenencia. Por ello es más adecuado atenerse a las coordenadas apego-interacción, "attachment-interplay".

13 En las que simultáneamente estaba presente el control por vía grid, mediante ordenanzas y división del trabajo. 
[b] Si suscita densa interacción pero despierta escaso interés simbólico-atractivo, es principalmente de agricultura intensiva.

[c] Si promueve intensa atracción y reconocimiento, pero establece una malla débil de relaciones, se trata de paisajes museificados, o del continuo ajardinado, repulido, apantallado y protegido de ciertos parques residenciales y destinos turísticos selectos.

[d] Cuando no suscita reconocimiento ni promueve vínculos interpersonales, es distal.

Nótese que la estructura de clasificación elegida, en dos ejes, impide acoger los tres ejes presentes en el no-lugar de Augé, definido por la ausencia de lo identitario, lo relacional y lo histórico. El tercer eje, el histórico, estaría en principio ausente del modelo. Pero, a grandes rasgos, la dimensión temporal encuentra cabida en el eje de apego ("attachment") pues solo es concebible que florezca la atracción hacia un paraje si la frecuentación prolongada y la continuidad histórica lo permiten.

Figura 1. Dos dimensiones (interacción y apego) para cuatro paisajes. Ámbitos no urbanos

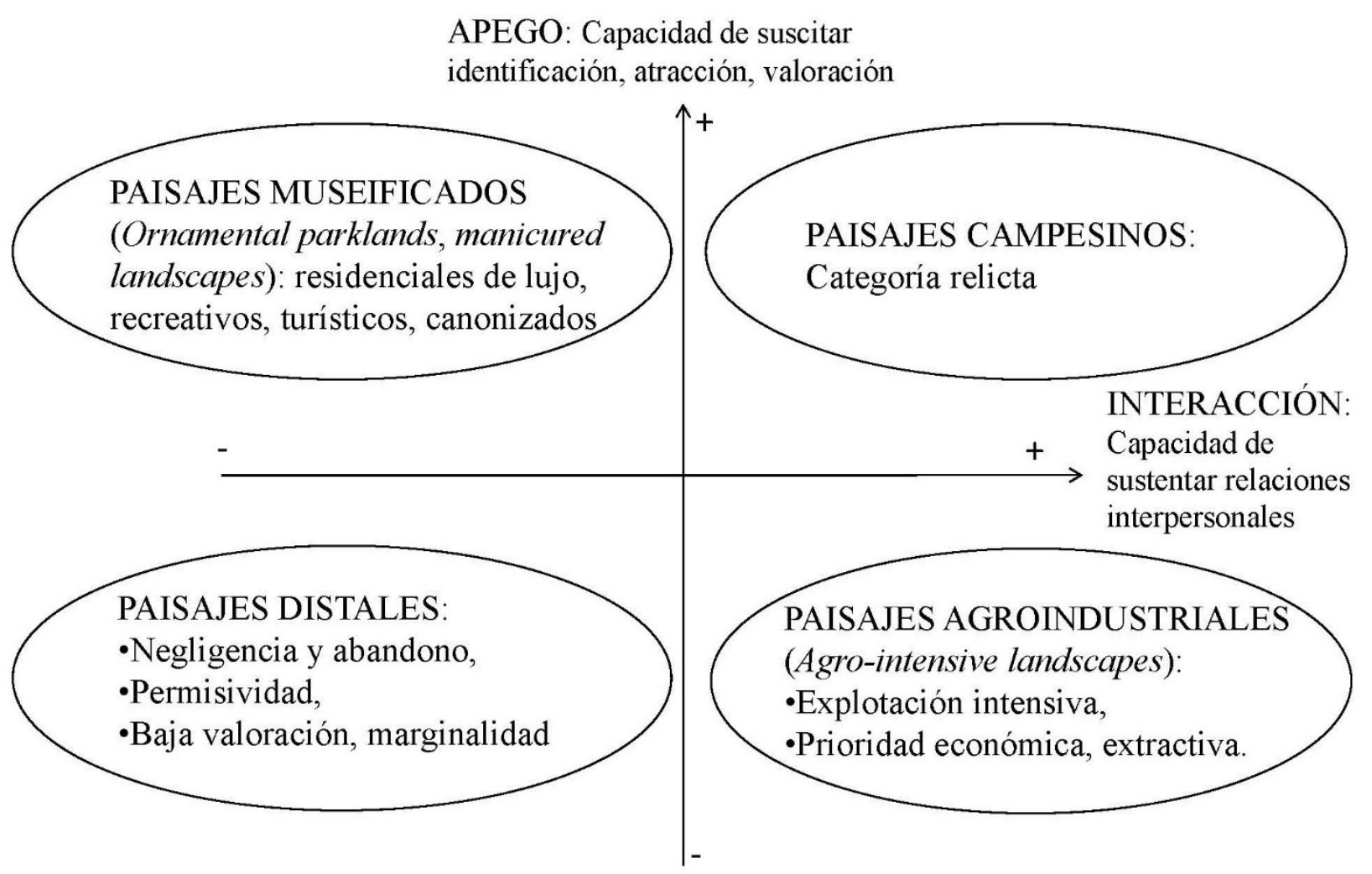

Fuente: elaboración propia a partir de Riesco Chueca (2003, p. 60)

Estos cuatro tipos admitirían extrapolación, basada en los mismos ejes atracción-interacción, para incorporar los paisajes urbanos. La Figura 2 intenta representar el esquema correspondiente. 
[a] Barrios consolidados, armoniosos, densos y bien avenidos, así como algunos centros vitales de viejas ciudades, que mantienen rasgos de potente cohesión y apego.

[b] Polígonos industriales y barrios de oficinas, donde la interacción es densa, pero escasa la capacidad de suscitar apego e identidad.

[c] Urbanizaciones privilegiadas (en un espectro de manifestaciones, desde los condominios y barrios cerrados iberoamericanos, a las "gated communities" de los EE UU), que se atrincheran en el seno de las ciudades: espacios de definición esmerada, carecen en general de interacciones densas, pues cada parcela es un mundo separado.

[d] Solares, intersticios y ángulos muertos, ruinas de almacenes y fábricas. Es un conjunto de espacios marginales a los que atinadamente denominó Hetherington (1997) malpaíses urbanos ("badlands of modernity").

Figura 2. Dos dimensiones (interacción y apego) para cuatro paisajes. Ámbitos urbanos

APEGO: Capacidad de suscitar identificación, atracción, valoración

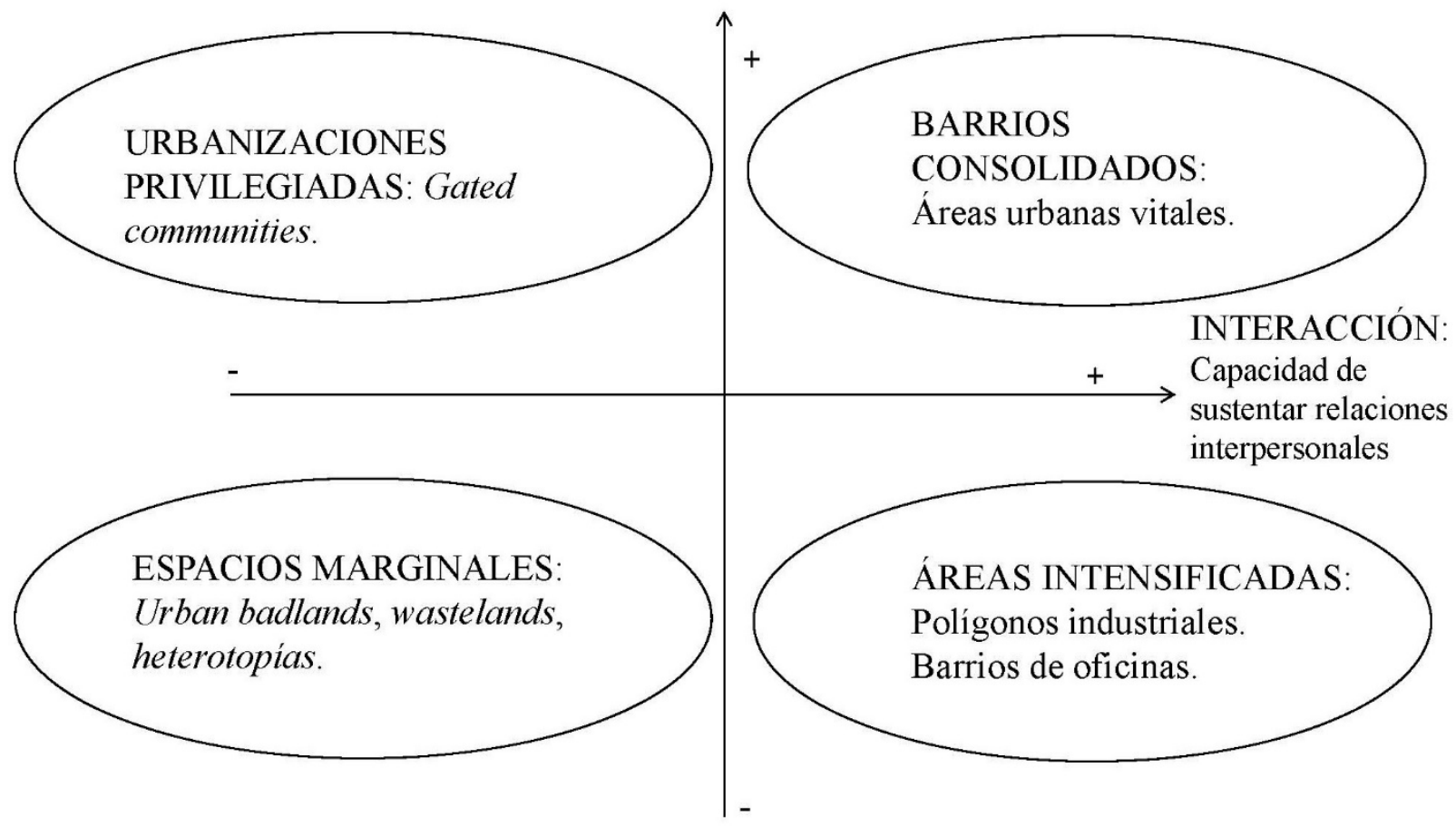

Fuente: Riesco Chueca (2003, p. 60)

Ahora bien, el hecho paisajístico en la ciudad no se deja cerrar mediante teorizaciones simples. Entre retazos que admiten clara identificación se extiende una masa de tonos grises, híbrida, 
ambigua y difícil de interpretar. Y las rápidas dinámicas de la moda, los raudos movimientos migratorios y de ocio, así como la extrema velocidad de transformación espacial debida a cambios socio-culturales y nuevas tecnologías, se aúnan para quitar estabilidad y desdibujar límites interiores en las coronas metropolitanas. Ello lleva a una parte de la teoría a centrarse en la ciudad compacta (Zoido Naranjo, 2012), sin que falten importantes aportaciones consagradas a fenómenos como el desparrame o "sprawl" (Kolb, 2008); es de destacar asimismo la teorización de Francesc Muñoz (2008) sobre urbanizaciones clónicas de baja densidad en la periferia urbana, que engloba en el neologismo urbanalización.

Como muestran los ejemplos, los ejes atracción-interacción son independientes. Determinados paisajes (tipo [c], paisaje no urbano) son altamente valorados en el imaginario de un pueblo, sin que por ello hayan fijado relaciones personales. Puede citarse el ejemplo del macizo del Canigó para la cultura catalana. Los residentes tradicionales de su entorno, pastores y leñadores que contemplaban su cima y la usaban de referencia territorial, han ido cediendo el paso a distintos nichos urbanos del ocio, deporte y turismo: montañeros, esquiadores, excursionistas. Una alta valoración del lugar no impone la existencia de una fuerte capacidad aglutinadora: quienes tan intensamente aprecian el Canigó ni viven próximos entre sí ni tienen por qué conocerse. El aprecio que muchos tienen hacia este distinguido macizo pirenaico tiene su expresión en el ámbito identitario, que no prescribe conocimiento mutuo, relación personal, ni teje constelaciones entre los apreciadores. Una situación análoga se presenta en ciertos espacios naturales, campos de golf y parques residenciales, en los que ha ido extinguiéndose la actividad y poblamiento tradicionales, desplazados por nuevos usos de visitantes y residentes ocasionales, que crean paisajes muy diseñados y pulidos, de esmerada jardinería. En lengua inglesa se usan los expresivos términos "ornamental parkland", "manicured landscapes" para estos paisajes lujosamente residenciales, en los que la cohesión entre personas es laxa y poco sostenida en el tiempo. En todo caso, algunas de estas categorías suscitan, inevitablemente, la controversia. Es el caso de las "gated communities" (barrios cerrados en Iberoamérica: véase Demajo, 2011), áreas residenciales segregadas que, si bien suelen evocar el privilegio y la exclusión, también podrían suponer alguna inyección de recursos para los barrios pobres adyacentes (Sabatini \& Salcedo, 2007).

En otro extremo, [b], se sitúa por ejemplo el paisaje almeriense de los campos de plástico, cultivos en invernadero (Silva, 2011). Son espacios en general poco valorados como lugar de residencia, escasamente inspiradores como elementos identitarios de la provincia, rehuidos por el turismo. Sin embargo, su alta productividad y la necesidad de una estrecha cooperación entre 
jornaleros, agricultores, transportistas y exportadores inscriben espacialmente a las personas mediante redes de interacción, no carentes de fricción, pero siempre activas y ramificadas.

El paisaje campesino, [a], en raudo proceso de extinción a expensas de los tipos [b-d], que no dejan de expandirse, obligaba a tejer densos lazos cohesivos entre los habitantes de la aldea; y el ruedo vivido por ellos, un área que aseguraba su subsistencia, estaba intensamente simbolizado y valorado, poblado por relatos y memorias. En los barrios consolidados y armoniosos, en comunidades rurales densamente vividas, que generan apego, historia e interacción, se expresa también el tipo [a]. En todos estos casos, se crean condiciones para la manifestación plena del lugar.

Interesa particularmente para el presente estudio el tipo distal [d], caracterizado por una doble ausencia. Tales paisajes no son reconocidos, no reciben aprecio ni miradas, no sirven para aportar identidad; pero tampoco vinculan a las personas, libres de atravesarlos sin atención, o de apartarlos de su mente, relegándolos a trastienda y desguace. Son distales en el afecto y el sentido de grupo, no en el de la distancia física. Algunas ciudades mediterráneas se ven rodeadas por extensos campos de cascotes y hierbajos, paralizados en una tensa o abúlica expectativa de lucro. Estos espacios no nutren la imagen de la ciudad, cuidadosamente expurgada de esas descoyuntadas extensiones de sí misma. En cierto modo componen el reverso de la convivencia, un vertedero de posibilidades sociales; un espacio anómico o permisivo donde el decoro no preside las formas del paisaje; y donde lo normativo no intenta cultivar la buena vida, sino que se limita a algunas prescripciones sumarias ("prohibido arrojar basuras", "agua contaminada: no beber"). Son solares e intersticios entre infraestructuras, que actúan como vertederos no declarados, como sitios de quema y acumulación; son campos de negligencia y abandono, que se convierten en vastos desguaces.

¿Cómo se producen los paisajes distales? Son el resultado del fracaso, el abandono, la acumulación excesiva, o la expectativa de lucro. Los intentos de intensificación agraria, a veces abocados a sonoros descalabros (por agotamiento del agua de riego, contaminación de suelos, contracción de los mercados), pueden dar lugar a extensos paisajes ruinosos de plásticos y tuberías, que por su propia inercia invitan el desaliño galopante. Las urbanizaciones rústicas, de segunda residencia, a veces fracasan; el resultado es un paisaje, inicialmente de buena calidad -elegido precisamente por ello-, que queda troceado, compartimentado por alambradas y sembrado de esqueletos de chalés o improvisadas casetas, toldos y prefabricados. Una situación 
parecida es provocada por la contaminación de suelos o por crisis ambientales como los incendios forestales, que promueven el abandono y el desinterés.

La acumulación, atributo inevitable en la economía de mercado, se ve constreñida en el entorno urbano por límites objetivos, como la escasez de espacio (análogamente, un apartamento no puede acumular indefinidamente trastos sin volverse inhabitable), las ordenanzas estrictas, la estrecha vigilancia intervecinal. Pero en áreas periféricas de los núcleos urbanos, en urbanizaciones desreguladas y en algunos polígonos, el proceso acumulador avanza sin trabas, pues los espacios en cuestión son socialmente invisibles (un rasgo que se radicaliza al adquirir la plena condición distal), por lo que no causa alarma la paulatina acumulación de chapas, láminas de tejado, maquinaria agrícola en desuso, contenedores de plástico, neumáticos viejos, bloques de hormigón, placas solares, montones de botellas, lonas y plásticos. Es un síndrome de Diógenes rural, aparentemente benigno porque se desparrama espacialmente, pero de crecimiento indefinido, por lo que su potencial degradante es intenso. Una vez iniciada la dinámica de degradación, el paisaje resultante es cada vez menos sentido como merecedor de cuidado y se radicaliza su invisibilidad. Ello invita a agudizar el proceso que, en el límite, convierte grandes extensiones en un desguace a cielo abierto. La expectativa de lucro, por su parte, afecta a ámbitos próximos a los ejes previstos de crecimiento de ciudades, pueblos e infraestructuras. La confianza en que el suelo vale más como ficha para especular que por sus rendimientos lleva a suspender el cultivo, con lo que se crean vastos campos de abandono, susceptibles de convertirse en improvisadas escombreras. Es un caso extremo de predominancia del valor de cambio sobre el valor de uso.

De nuevo ha de mencionarse la concentración parcelaria. Por lo general hecha sin criterio territorial ilustrado, es a veces un primer paso hacia la distalidad. En efecto, muchas concentraciones implican el borrado de la memoria del territorio, en un proceso que cabe describir como "Entortung" en el sentido de Schmitt, rayano en la evisceración del territorio: se derriban fuentes, humilladeros, palomares, muros de piedra, se sepulta la red caminera con sus puentecillos y cruceros, se talan árboles viejos, se cambia la orografía, se entierran valles, cañadas y lagunas (Martínez Carneiro, 1997). En esta operación, asimilable a un raspado de matriz o a un borrado del rostro, el paisaje pierde su conexión histórica, quedando sin inercia, a la merced de dinámicas descontroladas de rapiña y su envés, el abandono.

Ha de observarse que en el concepto de distalidad resuenan ecos de otras teorizaciones. El concepto de "yermo social" (inglés "impermanence syndrome"; francés "friche d'attente"), que 
se ha aplicado figuradamente para caracterizaciones sociológicas, a veces se desplaza al correlato paisajístico de tales situaciones, ${ }^{14}$ áreas que muestran el abandono y el desinterés de la sociedad, entroncando con la categoría que aquí denominamos distal. Una cita de Mignon (1982, p. 388), referida a la Costa del Sol malagueña - "el 'yermo social' tiende a rellenar los vacíos de la urbanización" - documenta cómo la radical transformación crea espacios distales por descarte.

Es también de interés la heterotopía de Foucault (1984), causada por redes de relaciones inconmensurables, que no se dejan superponer sobre un bastidor común. En la aplicación del término heterotopía a intersticios urbanos y solares sin ley (en francés "terrains vagues"; en inglés, "wastelands") puede detectarse cierta incipiente reivindicación: se les atribuye la cualidad de espacios transgresores, abiertos a juegos colectivos que se desarrollan a espaldas de los consensos principales de la sociedad. Es destacable la colección de ensayos recogida en Dehaene y De Cauter (2008). Aspirando a situarse en una posición más neutra, Hetherington (1997, pp. 20-38) revisa aportaciones teóricas que reivindican los espacios marginales como focos de resistencia y transgresión contra el orden hegemónico. Brogden (2019), por su parte, desarrolla en un libro ensalzador de los no-lugares una apología de ciertos espacios residuales y degradados que se alejan de la definición de Augé y que más bien cabría calificar como distales. Una relajación similar del concepto se aprecia en el excelente libro de fotografía de Francesco Nencini (2005).

Así pues, se registra a menudo una aplicación laxa del concepto de no-lugar, reteniendo tan solo los marcadores negativos (no relacional, no identitario, no histórico) pero olvidando de la teoría de Augé el aspecto hiperdiseñado, contractual, regulador de acceso y circulación. La definición incompleta del no-lugar crea un tipo que se despega de los ejemplos tratados por el autor, y que viene a converger con los aquí llamados paisajes distales, áreas donde el desaliño, la desatención, la falta de cuerpo social vinculado produce una carrera hacia la degradación. Algunos rasgos de lo distal son, en efecto, antitéticos de lo propuesto por Augé para el no-lugar: si este presupone diseño y control, lo distal equivale a desinterés y abandono; si los no-lugares regulan su acceso mediante un tique, una tarjeta, un justificante, los paisajes distales son permisivos por pura indiferencia. En efecto, los no-lugares de Augé cotizan alto en la dimensión

14 Debo esta sugerencia al profesor Leandro del Moral Ituarte. Paül i Carril (2010, p. 147) ofrece algunas propuestas de traducción y una breve introducción teórica al término "friche d'attente". 
llamada "grid" por la teoría cultural: controles ejercidos por vía contractual, anónima y abstracta, sin recurrir a las presiones de grupo (Douglas, 2005).

Aunque Augé no lo indica expresamente, el no-lugar presupone dos tiempos. Uno, en primer lugar, de vaciamiento, en el que se expurgan las trazas, relaciones y condiciones propias del lugar. A ello le sigue la instalación de un potente artefacto espacial para control de movilidad, acceso y permanencia. Podría pensarse que esta sucesión es banal en la historia, con dialéctica de destrucción-construcción, e incesantes borrados y reescrituras sobre el lienzo geográfico. Pero lo distintivo, lo históricamente específico del no-lugar es la actual potencia tecnológicosocial, que instituye la radicalidad del borrado y la radicalidad del artefacto. Las viejas tecnologías y configuraciones sociales eran impotentes para producir transformaciones rotundas; se limitaban a injertar modestas tramas de cambio, que solo determinaban alteraciones drásticas en el largo plazo. Kundera (2000: 59) imagina un Ulises que, al despertar tras su retorno a Ítaca, es incapaz de reconocer su isla: "la gigantesca escoba invisible que transforma, desfigura, borra paisajes, viene trabajando desde hace milenios, pero sus movimientos, antes lentos, apenas perceptibles, se han acelerado de tal manera que me pregunto si La Odisea sería hoy concebible. ¿Pertenece aún a nuestra época la epopeya del regreso?".

Lo distal emerge cuando el segundo tiempo no llega o se aplaza indefinidamente: paisajes que han sido expurgados, eviscerados, y se quedan esperando. Son los solares, o las dramáticas concentraciones parcelarias en las que, tras quedar arrasado un término municipal, los escasos vecinos siguen abandonando los cultivos o emigran en masa.

Regresando al esquema de clasificación sobre los ejes apego-interacción, surgen ciertamente factores contemporáneos que enturbian los límites entre tipos, problematizando la clasificación. Seguidamente se consideran en mayor detalle los elementos perturbadores en la actual relación con el espacio. Esta es una relación cada vez más inscrita en lo performativo (dependiente de la acción ejecutada en su marco), de creciente virtualidad y sometida al efecto amnésico de las intermitencias. El intento de aclarar estos factores, que dificultan la cristalización de los paisajes en tipos nítidos, lleva a discernir algunos elementos destacados:

- La expansión de los tejidos urbanos. Como se indica anteriormente, los tipos [a-d] no son de inmediata extrapolación a contexto urbano, por lo que las ciudades, cada vez más desparramadas, crean situaciones intermedias, de compleja caracterización. En general, si no hay una ordenación cuidadosa, sus ruedos se dilatan devorando paisaje y poniendo como avanzadilla un mosaico compuesto por parajes distales (las bolsas de suelo 
estrangulado en terrenos de descarte), no-lugares en el sentido de Augé (como las grandes superficies de ocio, transporte y comercio), polígonos industriales y oficinas ([b]), urbanizaciones blindadas ([c]) y retazos de nueva ciudad ([a]); y, entre enclaves de rasgos definidos, extensas áreas grises.

- La relación cada vez más efímera y discontinua con los paisajes no urbanos. El ocio y el trabajo, los viajes de placer o profesionales se amoldan a pautas de contacto intermitente con los lugares. Un campesino estaba en el Antiguo Régimen estrechamente unido a los paisajes de los que dependía su sustento: y no solo durante las horas de labranza sino en la totalidad de su vida. No ocurre lo mismo con una agricultura altamente tecnológica que, salvo excepciones, puede practicarse desde la distancia.

- La vigencia creciente de la movilidad, tanto en la marcha de la historia como en la teoría, con innumerables campos de estudio - desterritorialización, diáspora, migración, viaje, fronteras, nomadismo-, un auge que ha venido a eclipsar en parte el interés por el lugar, al que ocasionalmente se considera un baluarte esencialista (Escobar, 2001, p. 141). Se viene concediendo especial atención al sentido de lugar en espacios migratorios internacionales. Mendoza y Bartolo (2011) lo evalúan en la periferia de la Ciudad de México, revisando las categorías de lugar, sentido del lugar y ausencia de este ("placelessness"). Con otros autores, su trabajo refleja el llamado "giro hacia la movilidad" ("mobility turn": véase en Urry, 2007) en los estudios geográficos.

- Los procesos de virtualidad. En los espacios dominados por lo virtual, el contenedor se vuelve discreto y oscuro; su función principal es sustentar escenarios de ficción espacial: se alude mediante citas y simulaciones a los lugares antropológicos, pero ello ocurre como en juego de disfraces. En el caso de parques temáticos y ciudades del juego se consuma la invención de tradiciones y la síntesis artificial de efectos urbanos (Arefi, 1999, p. 185). Nuestra relación con el patrimonio se basa en una retrospección selectiva o "filiación invertida", de carácter cultural y no ajena a la llamada invención del pasado (Davallon, 2006). En el cinematógrafo, las propiedades espaciales intrínsecas (arquitectura de la sala) palidecen ante la espacialidad virtual ofrecida por la pantalla. Todavía en los teatros y salas de ópera decimonónicos, la situación era más equilibrada. Existía sin duda el ámbito espacial de la ficción, pero los encuentros y cruces de miradas, con o sin los indiscretos gemelos, las visitas a palcos, el roce social y el galanteo en pasillos y escaleras: todo componía un escenario de rica relación. Actualmente, sin 
embargo, la potencia de lo virtual lleva a desdibujar los trazos firmes del paisaje bajo capas de experiencia virtual añadidas por diversos intereses de consumo. Estos espacios de arquitectura muda evocan por su carácter al "hangar con apliques" ("decorated shed") de Venturi, Scott Brown e Izenour (1972): un gran contenedor de sumaria arquitectura, abundante en planos disponibles, donde todo el programa estriba en megarrótulos, apliques, proyecciones e imágenes que ocupan las superficies, convertidas en lienzos para la impresión. Es el caso de las grandes superficies comerciales: sus naves son simples estructuras tubulares diáfanas, ricas en posibilidades para instalar planos de escritura en el espacio interior (pancartas y banderolas) o para revestir con iconografía publicitaria las fachadas. La arquitectura se vuelve muda, eclipsada por su nueva función, la de soporte y marco para presentaciones, como en un atril o caballete de conferencias. Todo ello remite, por otra parte, a la descripción por Augé del hipermercado: un ejemplo de la invasión del espacio por el texto, un rasgo para él característico de los nolugares, donde los individuos parecen interaccionar solo con textos (Augé 1992, pp. 120-121).

- Los "sucesos espaciales". Una copiosísima presencia humana se condensa y arremolina en ciertas ocasiones (playas, campos de refugiados, grandes conciertos); las aglomeraciones resultantes adquieren inercia propia, sepultan la base paisajística permanente y pueden desplazarse sin perder su identidad.

En lo que sigue se exponen en síntesis algunas contribuciones sobre el concepto del lugar. En ellas se investigan los ingredientes de plenitud de ciertos espacios que merecen plenamente la denominación de lugar.

\section{La conformación de lugares vividos y apreciados: algunas líneas de análisis}

La teoría del planeamiento urbano, sometida a intensas controversias tras el final de décadas de hegemonía del movimiento moderno, produjo interesantes indagaciones acerca de qué componentes conferían calidad y éxito social a un lugar dentro de la ciudad. A partir de aportaciones previas (Relph, 1976; Canter, 1977; Lynch, 1981; Punter, 1991), Montgomery (1998, pp. 97-101) describe un modelo basado en tres premisas que deben concurrir para la consolidación de un lugar satisfactorio. Dicho modelo se ajusta en sus detalles a la caracterización del paisaje urbano, pero, como se argumenta más abajo, sus conclusiones son 
en buena parte extensivas al paisaje en general, en especial si se atienden las indicaciones de tratados internacionales como el Convenio Europeo del Paisaje.

(1) Actividad: reúne las nociones de vitalidad, frecuentación y polivalencia. La presencia continuada y diversa de personas que hacen uso de un espacio, multiplicada por un sinnúmero de ajetreos asociados a él. La clave estriba en la multiplicidad de usuarios, repartidos por distintas franjas del día, con multiforme actividad.

(2) Forma: incluye los aspectos materiales del paisaje en su organización; se ajusta a la definición clásica de la forma del tejido urbano y de las arquitecturas presentes.

(3) Semblante o imagen: abarca aspectos de fisonomía y de significación. En la significación, a su vez, intervienen condiciones de legibilidad (determinados en gran parte por el trazado y diseño de las vías) y factores culturales intangibles, como la carga simbólica y la acumulación de memorias.

La actividad, (1), puede aproximarse a un concepto bien desarrollado por la antropología contemporánea, el de la agencia ("agency"); y, sin excesivos quiebros en la perspectiva, le es también aplicable el componente performativo (Thrift \& Dewsbury, 2000), importante en una nueva geografía que concede especial importancia a las tramas de acción coral o individual suscitadas por esta partitura implícita, el espacio vivido. El que aquí denominamos semblante (3) se sitúa en el plano de los constructos culturales y simbólico-imaginativos forjados a partir de la sedimentación y reproducción de la experiencia. Menos problemático es el factor forma (2), rama de estudio bien nutrida por una rica tradición, la teoría del urbanismo y la arquitectura.

Una conceptualización flexible del paisaje permite aprovechar estas elaboraciones teóricas, originariamente urbanas, para los paisajes en general. Viene consolidándose una noción de paisaje integradora, lejana de la idea escenográfica y esencialista de los paisajes canónicos objeto de una primera atención pública. Es conocida la transición que lleva de unos primeros paisajes protegidos en virtud de su excepcional calidad escénica (Yellowstone, Picos de Europa: véase en Smith, 2004 y en García Álvarez, 2009) a una interpretación abierta, que reconoce valores y contribuciones fundamentales al buen vivir incluso en paisajes cotidianos $y$ descuidados. En tal transición son esenciales dos teorizaciones aplicadas: el "Landscape Character Assessment" (LCA) británico, con su insistencia en conjugar el binomio "people and place"; y el Convenio Europeo del Paisaje, que extiende la acción paisajística a la totalidad del espacio geográfico, amén de incorporar la percepción pública de los lugares en la propia definición de lo que un paisaje es. 
Por esta y otras vías, las aportaciones a la teoría del lugar contribuidas por los analistas del hecho urbano pueden encontrar acomodo en marcos espaciales más extensos, con tan solo algunas adaptaciones ampliadoras. No es difícil generalizar el campo de actividad (1): un paisaje rural pone el chasis sobre el que se entrelazan numerosos hilos de acción: paseantes, cazadores, viajeros en tránsito rápido, agricultores, ganaderos, residentes, turistas. Sus pautas de acción en el paisaje se ajustan, no menos que un marco urbano, a distintas intensidades en cuanto a vitalidad y diversidad. En cambio, la forma, (2), en paisajes no urbanos, ofrece cierta dificultad debido a la constante interferencia o resonancia entre la base natural y el artefacto humano, capas que incesantemente se sobreponen y amalgaman produciendo inextricables resultados, a veces difíciles de analizar. Solo en paisajes prístinos, de discutible existencia en Europa, puede darse una neta supremacía de la base natural, que pasa a dominar casi del todo la forma del lugar. En el resto de los casos, abrumadoramente más comunes, la rúbrica (2) comprende una amalgama de naturaleza y artefacto, rica en capas de problemática jerarquización, categorías incesantemente subvertidas la una por la otra, pero que la teoría y práctica del paisaje viene integrando con mayor o menor éxito. En el tercer ámbito (3) se acumula la percepción, en su inextinguible condición histórica, presente en paisajes rurales a través de los legados: cultura oral, patrimonio disperso, inercias de zonificación. Toda percepción (como despliega Gadamer en su hermenéutica: véase Dostal, 2002) es diálogo con percepciones previas, que refuerzan como cámara de resonancia las impresiones, o que obstaculizan la detección de lo nuevo, por inercias difíciles de superar. Aquí, tanto en la ciudad como fuera de ella, pueden desplegarse procesos que dotan de significado y permiten la lectura cultural de un espacio vivido. La Figura 3 muestra el diagrama de Venn elaborado por Montgomery (1998, p. 98), al que se le han introducido leves adaptaciones que lo hacen en gran medida extensivo a espacios nourbanos.

No es trivial buscar acomodo en este esquema, sin duda seductor, para la teoría del no-lugar de Augé. Los atributos usados por Augé (identitario, relacional e histórico) no coinciden con las tres esferas de Montgomery (actividad, forma, lecturas). La ausencia del apartado formal en Augé no debe sorprender en un encuadre antropológico, más interesado en lo interpretativo que en el análisis de las materialidades. Precisamente, al omitir lo formal, su teorización se adapta bien a nuevas situaciones como la gran superficie - un contenedor arquitectónicamente mudo; primacía del acontecimiento de consumo masivo-, los espectáculos y acontecimientos basados en los efectos especiales y la virtualidad, o las infraestructuras dominadas por el control de flujos de tráfico o de personas. Particularmente en estas últimas es más importante la topología (la 
abstracción en forma de grafo que reproduce el esquema de movilidad) que la forma urbanística y arquitectónica. En el límite, el no-lugar ni siquiera tiene que estar anclado a unas coordenadas espaciales, pues admite desmontajes y reinstalaciones raudas. En cuanto a lo identitario, lo relacional y lo histórico, aunque por diversas vías teóricas, es posible seguir sus trazas en las tres esferas de Montgomery.

Figura 3. Tres esferas definitorias del lugar pleno

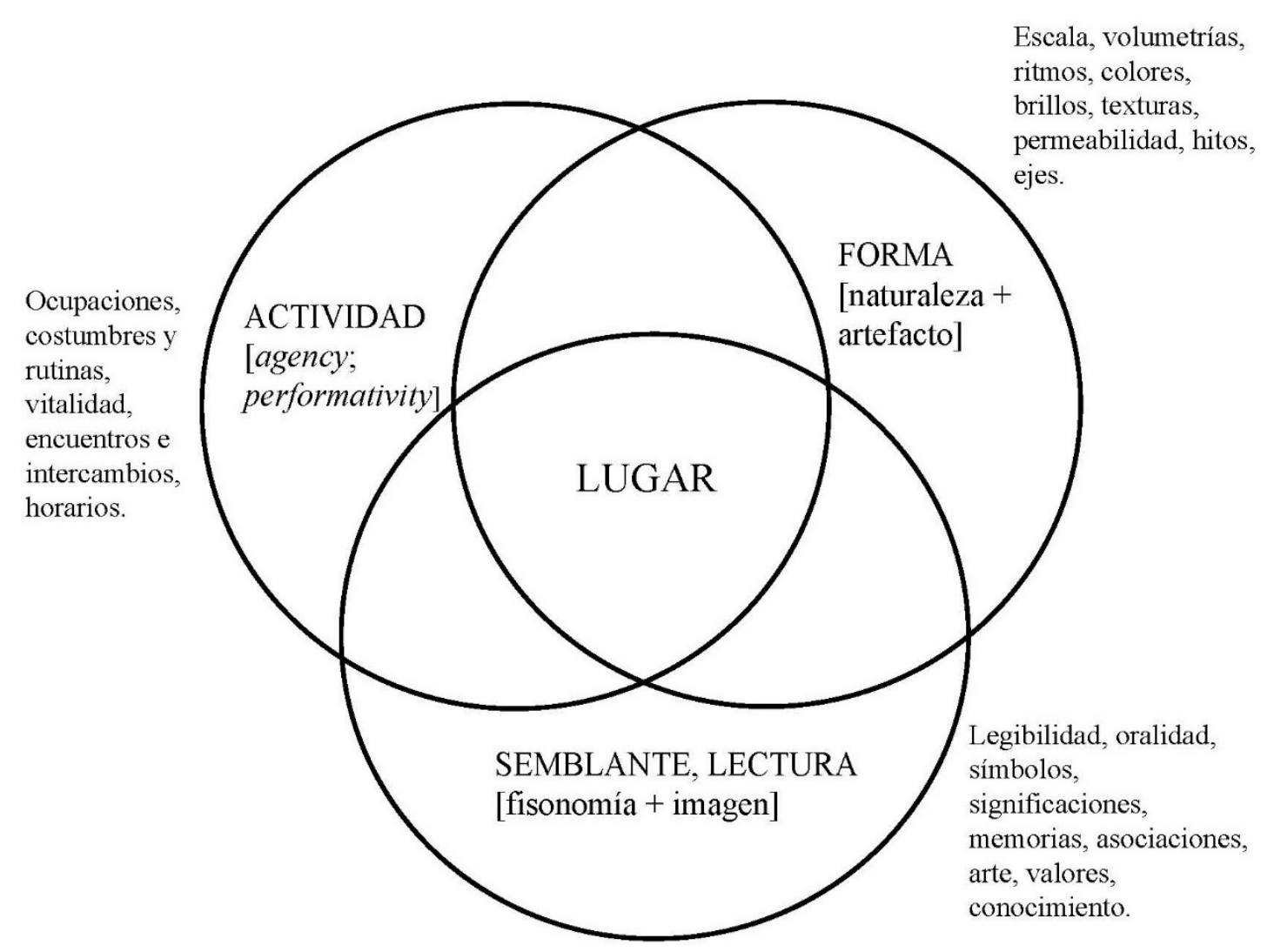

Fuente: adaptación a partir de Montgomery (1998, p. 98)

Se avanza seguidamente una hipótesis: las potentes dinámicas de la contemporaneidad causan la divergencia entre estas tres esferas, reduciendo su grado de conformidad y solape. Interpretando en sentido fuerte el diagrama de Venn en cuestión, ¿̇qué significaría un grado de solape grande (amplio porcentaje de intersección) entre los tres ámbitos actividad-formasemblante?; ¿̇y qué significaría la ausencia de solape entre dos o entre los tres ámbitos? La respuesta tiene que radicar en cómo de nutrido es el universo de quienes despliegan actividad, crean oralidad o experimentan formas en el citado lugar. 
En las sociedades campesinas tradicionales, las tres esferas (1-3) presentan extensos solapes: el conocimiento minucioso de la forma (caminos, atajos, barrancos, arboledas, fuentes) nace de una rica maraña de actividades cotidianas (labrar las tierras, cazar, apacentar el ganado, dormir en el campo, buscar agua) y suele ir de la mano con un simultáneo florecer de las lecturas (toponimia, narrativa espacial, sacralidad). Este triple solape es una consecuencia o, si se quiere, una condena, del modo de vida campesino, que contiene tanto de intensidad como de servidumbre. No es el caso de muchos desarrollos urbanísticos actuales, cuya organización material es clara y notoria para planificadores y residentes, sin que por ello haya una diversa y poliforme vida pública, lo cual obstaculiza la aparición de un plano de crítica, interpretación y simbolización.

Otra variante de no-intersección significaría, por ejemplo, que quienes son activos en el lugar no coinciden con los portadores de memorias, con los creadores de arte y crítica, con los estudiosos o emisores de símbolos. Determinados paisajes espectaculares en latitudes exóticas, visitables ahora gracias a la generalización del viaje turístico de largo recorrido, mostrarán evidencia de un frágil solape entre el ámbito de la forma y el ámbito de las lecturas. Quienes se deleitan, por ejemplo, con los puros patrones geométrico-cromáticos de una cordillera neozelandesa, muchos de ellos visitantes foráneos, pueden padecer de un débil anclaje con el universo de simbolizaciones y lecturas heredado, con los topónimos locales y la literatura oral alusiva.

En no pocos centros comerciales, el puro éxito de la función de consumo determina un denso entrecruzamiento de actividades asociadas, relativamente ciegas al contenedor, que hace que cualquier engarce entre actividad, forma y simbolización sea problemático. ¿Qué microtoponimia, qué oralidad consolidada pueden generarse espontáneamente en el interior de unos grandes almacenes? Toda referencia espacial es provisional y se basa en módulos y recorridos, que son previstos por una administración lejana siguiendo inescrutables estrategias y campañas. Los avances de la virtualidad, por otra parte, dan lugar a intensos cambios en cuanto a modos de cohesión. Los usuarios de un espacio pueden tener residencia cada vez más remota entre sí y atravesar unos mismos parajes, ya sea de visita o de paso, sin el menor conocimiento mutuo.

Un solape amplio de las tres esferas, por el contrario, implicaría una extensa base social de personas que simultáneamente (1) transitan, se recrean y ajetrean en el lugar; (2) elaboran y recrean memoria, arte, símbolos y conocimiento; (3) conocen y reconocen las particularidades 
formales del lugar, sus rincones, sus caminos, sus sitios de sombra y sol, sus vistas. Y para que los tres ingredientes postulados por Augé -identidad, relaciones, historicidad- fructifiquen, es preciso que dicha base social se prolongue en el tiempo y se transmitan diacrónicamente percepciones y debates. La perduración en el tiempo parece imprescindible para el apego espacial o querencia ("place attachment": Altman \& Low, 1992).

Roach (1996, pp. 27-28) acuña un término, "arremolinamientos conductuales" (mi traducción de "vortices of behaviour") que aplica a la poderosa, desbordante auto-expresión catalizada por algunos núcleos del paisaje urbano occidental: el bulevar, el mercado, el barrio de cine y teatro, la plaza mayor. En ellos, el magnetismo del comercio y el disfrute ejerce una succión potente hacia residentes y visitantes. En el límite, la actividad desplegada se convierte en liberadora de otras prácticas y atracciones cotidianas, que encuentran en tal ámbito un crisol de reforzamiento, celebración e intensificación. En tales casos, a los que Roach denomina "aconteceres condensatorios" (id. para "condensational events"), la potencia con que el acontecer se agarra a la memoria colectiva crea inercias tales que el hecho en sí puede sobrevivir cambios drásticos: no solo la transformación del espacio donde por primera vez floreció ese acontecer, sino incluso el traslado a otro punto del mapa. Se trata por tanto de sucesos espaciales no anclados, por lo que la imagen de un torbellino o tornado, que se desplaza sobre el mapa, parece muy apropiada; en tales sucesos, la querencia o apego topográfico es aspecto secundario y opcional. Un celebrado poema de Aleixandre ilustra con clarividencia la cívica floración del gentío adueñándose de una plaza:

Era una gran plaza abierta, y había olor de existencia.

Un olor a gran sol descubierto, a viento rizándolo, un gran viento que sobre las cabezas pasaba su mano, su gran mano que rozaba las frentes unidas y las reconfortaba.

Y era el serpear que se movía como un único ser, no sé si desvalido, no sé si poderoso, pero existente y perceptible, pero cubridor de la tierra.

Ahora bien, la plaza celebrada por los versos de Aleixandre contiene una nota de permanencia y continuidad histórica: es un lugar al que los ciudadanos regresan, del que se apropian cívicamente y que se abre cerca de sus vidas cotidianas. No es el caso de los espacios de un 
megaconcierto o una gran feria monográfica, que pueden florecer un día y luego pasar a otros usos, sin que permanezcan trazas territoriales de aquel acontecimiento.

\section{El no-lugar: ¿̇abe situarlo en la representación en dos ejes, apego- cohesión?}

Sorprende, si se admite como buena la clasificación mediante dos ejes antes descrita ("attachment-interplay", apego-cohesión), que el no-lugar, en el sentido establecido por Augé, no parezca encontrar directo acomodo dentro de ella. Ello invita a reflexionar sobre el engarce de estos tipos paisajísticos, ${ }^{15}$ y este problema, de índole taxonómica, entreabre la puerta a interesantes intuiciones. Sería incorrecto colocar el lugar en el tipo [a], poniendo el no-lugar en [d]. Pues aunque los paisajes tradicionales, consolidados y vividos son sin duda un importante reservorio de lugares antropológicos, lo distal solo parece compartir con el no-lugar de Augé las ausencias definitorias (no relacional, no identitario, no histórico).

El no-lugar se implanta a través de procesos de aguda intensificación, que llevan a un extremo la artificialización. Por así decirlo, las magnitudes relacional, identitaria e histórica postuladas por Augé se derriten. El no-lugar es deficiente en tales magnitudes, que en marcos como los aeropuertos, grandes superficies, cruces de autopista o "fingers" de un aeropuerto se vuelven impracticables. Augé encuadra esta condición dentro de lo que llama sobremodernidad (1992, pp. 35-50), un momento dominado por tres excesos: (A) la sobreabundancia de acontecimientos, que satura la atención y dificulta la aparición de valores y significaciones; (B) la sobreabundancia espacial, a través de una omnipresencia de vídeos e imágenes, la frenética movilidad y un planeta que se encoge por momentos; (C) la individualización de las referencias, mediante el acceso directo de cada uno a las fuentes, lo cual conduce a patrones de identidad cambiantes y caprichosos.

La emergencia de la sobremodernidad implica pues un derretimiento de categorías. Si la clasificación antes descrita está basada en dos ejes, uno de apego e identificación, otro de interacción, ambas coordenadas se colapsan cuando se imponen vectores que artificializan el apego, convierten la seducción espacial en un asunto de márquetin, y virtualizan y llevan a la nube la cohesión de sus "comunidades". Así pues, los dos ejes se vuelven líquidos, transitados por rápidos efectos de mercado, inflados como producto de incubadora. En el extremo, un no-

15 En síntesis, los cuatro tipos (a) tradicional campesino, (b) agroindustrial, (c) museificado o de jardín continuo, (d) distal, o sus correspondientes tipos urbanos, en su colateralidad con los no-lugares. 
lugar puede carecer de anclaje territorial, pues su montaje y desmontaje rápido permiten a estas macroestructuras despegarse de una ubicación. No menos líquido se vuelve el eje histórico. Al igual que entre los bares de un aeropuerto pueden encontrarse postizos bohíos caribeños, impostadas pagodas, falsas tabernas napolitanas, también en las grandes superficies del ocio se registra la carnavalización de la historia, un caprichoso archivo o bailes de disfraces evocador de viñetas pretéritas: el falso pub decimonónico, el acontecimiento gótico, la fiesta romana. Foucault (2004, p. 17) recalcó la conexión entre heterotopías y heterocronías: la síntesis artificial de espacios suspendidos se alía frecuentemente con los "découpages du temps", que cabría parafrasear, dando un giro metafórico, como operaciones de cortar y barajar en el mazo de naipes del tiempo.

Ante las vigorosas dinámicas creadas por la sobremodernidad, el no-lugar flota como posibilidad sobre todos los paisajes heredados, amenazando con sumergirlos. En particular, es previsible que una fracción creciente de los tipos (b-c) caminen acercándose al no-lugar. El requisito para ello es la radicalización del control y el constructo espacial. Si una explotación intensiva pierde la densidad de interacción entre agricultores, ganaderos, comerciantes y transportistas actualmente existente, si las operaciones agronómicas se vuelven tan tecnificadas que pueden hacerse a distancia, caen bajo el control de nubes financieras deslocalizadas, si la accesibilidad al espacio de los cultivos o granjas se regula herméticamente, el resultado será cada vez más afín a un nolugar. En el límite, tales explotaciones agrarias han de adquirir rasgos próximos a una plataforma petrolífera o una mina a cielo abierto. Un distrito de oficinas, o un estadio, sometidos a rigurosas disposiciones sobre acceso y permanencia, se aproxima también al no-lugar. En el otro extremo, si los paisajes ajardinados de un parque natural se sobrecargan de equipamientos de control hasta convertirse en escenarios por los que se mueven los visitantes como viajeros entre los cordones de un aeropuerto, de nuevo estarán insinuándose los rasgos del no-lugar.

Por el contrario, cuando las aspiraciones de hipercontrol espacial descarrilan, el resultado es un paisaje fallido, que puede considerarse distal: determinados cultivos se conciben como campañas a corto plazo hasta el agotamiento del suelo o el agua. Lo que quede tras el abandono de plásticos, estructuras, goteros, con topografías artificiales y sin suelo vegetal, estará a las puertas de ese agotamiento territorial que es la distalidad.

Fuera de paisajes bien planificados, abiertos a una integración plenamente inclusiva, puede temerse que muchas coronas metropolitanas, nudos industriales y de transporte, así como los denominados filamentos urbanos (Le Bras 1993, p. 126; tejidos filiformes a lo largo de la costa o 
enlazando núcleos urbanos), acaben dominados por un ajedrez a dos colores: teselas ocupadas por no-lugares, aeropuertos, disneyworlds, distribuidores de autopista; y teselas intersticiales, en los huecos sobrantes, entregadas a la dinámica negligente, permisiva, fuera de mirada, de los paisajes distales. En el límite, grandes superficies hipercontroladas; y, en los huecos, paisaje de desguace.

\section{Atributos asintóticos del paisaje: la aceleración de la historia y la entrada en crisis de conceptos como carácter, apego y cohesión}

Los conceptos centrales que categorizan el paisaje llevan implícito cierto grado de estabilidad temporal, sin el cual se vuelve difícil caracterizar el hecho paisajístico. Para los fines del presente artículo, se hace referencia a estos atributos paisajísticos como asintóticos: son propiedades que emergen como resultado de una sedimentación, decantación o convergencia que requiere plazos relativamente largos de tiempo para emerger. Se accede a ellos como a una asíntota, en un límite temporal. Con ello no quiere negarse el hecho de que los espacios se encuentran siempre sometidos a pugna, tanto en sus significados como en su evolución. Pero el pulso entre transformación y permanencia es insoslayable. Dieterle incluye, en referencia a los paisajes urbanos, una enjundiosa fórmula: "cabria definir la ciudad como un compromiso entre la ruina y la obra". ${ }^{16}$ Sin la huella de la historia, la ciudad pierde su tensión inherente; y el paisaje en general se centrifuga hasta desdibujarse.

Los paisajes europeos son inentendibles si no palpita en ellos el sedimento de la historia. La narrativa de W. P. Sebald ofrece una hipnótica reflexión literaria acerca del territorio, entendido como almacén de memorias, un vasto archivo "donde el pasado ha depositado trazas y fragmentos que han sido preservados y en muchos casos sistematizados, catalogados o indexados". ${ }^{17}$ Este espesor temporal del paisaje, que no implica ni escritura ni archivos en el sentido literal, es un atributo universal, extensivo a sociedades del todo ajenas a Occidente.

Comprobemos la necesidad de cierto grado de permanencia, acudiendo a una fuente bien consensuada, el Convenio Europeo del Paisaje. En la definición se introduce la conocida fórmula "cualquier parte del territorio tal como la percibe la población...". Aquí, aunque con calculada ambigüedad se evite declarar qué se entiende por población (¿̇residentes, nativos,

16 "On pourrait definir la Ville comme un compromis entre la ruine et le chantier" (Dieterle, 2003, p. 7).

17 "Places where the past has deposited traces and fragments that have been preserved and in many cases systematised, catalogued, or indexed" (Long, 2007, p. 11). Sobre los "paisajes de la memoria" sebaldianos, véase Catling (2003). 
transeúntes?), cabe entender que solo es posible una percepción colectiva si hay alguna medida de continuidad de trato, familiaridad, espesor temporal. En un no-lugar apenas cabría aplicar el concepto de población, pues ¿̇uién es la población de Disney World, o la de un aeropuerto o un peaje de autopista?, ¿han de tener prioridad los trabajadores fijos (que tampoco lo son tanto), o la rodante sucesión, casi amazónica, de visitantes canalizados por estas estructuras de ocio o transporte?

Por otra parte, intentando compensar el arranque subjetivo, la definición de paisaje contiene una segunda parte, "...cuyo carácter es el resultado de la interacción de factores naturales o/y humanos". Evidentemente, este concepto, el carácter, tomado en gran parte de la LCA británica, pieza crucial para la identificación de valores patrimoniales (Silva, Fernández \& Molinero, 2016), presupone sedimentación y estabilidad; el carácter es una asíntota a la que se tiende tras un proceso histórico de negociación entre lo antrópico y lo biogeográfico; de lo contrario, si las fluctuaciones son demasiado vigorosas, es imposible que esta interacción entre lo natural y lo humano cuaje para producir un resultado legible. Como el dado que da vueltas - de cuyos tumbos no vale la pena ser reportero-, tales paisajes son refractarios a la caracterización: ¿para qué intentar caracterizar algo que está en incesante mutación? La masa de simbolizaciones, lecturas, interpretaciones hilvanadas en torno a un lugar, su imagen o semblante, solo cuaja cuando se ha dado tiempo a un proceso que cabe metaforizar como un revelado fotográfico: las imágenes emergen lentamente de su sombra. Ya Certeau incluía la estabilidad como atributo destacado del lugar (por oposición a un mero espacio): "un lugar es por lo tanto una configuración instantánea de posiciones. Implica una evidencia de estabilidad". ${ }^{18}$ El monumento, en la ciudad clásica, es la expresión de una permanencia, o al menos, una larga duración (Augé 1992, p. 78). ${ }^{19}$ Y los tres vectores de la sobremodernidad (A-C) enunciados por Augé dificultan, cuando no imposibilitan, la sedimentación.

(A) La sobreabundancia de acontecimientos, para Augé, es una marcha frenética de los hechos, un vértigo que impide la decantación de significados. Bruscos volantazos de la historia, derrumbes y sorpresas crean una inseguridad que nos empuja a experimentar

18 "un lieu est donc une configuration instantanée de positions. II implique une indication de stabilité" (Certeau 1990, p. 173).

19 Es significativo que Brogden (2019, p. 124) encuentre la posibilidad de categorizar el no-lugar como un contramonumento. En efecto, si la memoria colectiva se formula como un ente cambiante, que debe subvertirse en una constante re-significación de lo público, el no-lugar (en rigor el libro describe paisajes distales: solares abandonados e intersticios urbanos) ofrece posibilidades pugnaces contra la fosilización de significados hegemónicos. 
déficit $-y$, consiguientemente, a generar demanda- de ciertos atributos que antes se daban por supuestos, como los valores y significados. Ello hace difícil la fijación del carácter. Augé no presta especial atención a la tecnología, pero merecería, sino un punto adicional en su modelo, al menos un enfoque atento dentro de (A). En efecto, se vive hoy día una insólita plasticidad del territorio a manos de la tecnología. La potencia de la maquinaria de movimiento de tierras, la construcción modular en formatos cada vez gigantes, la disponibilidad de geotextiles y plásticos, son factores omnipresentes que permiten cambiar de un plumazo la cara de un paisaje.

El discurso lento de los hechos, que ofrece marco temporal para que un trozo de espacio terreno adquiera carácter (en el sentido del Convenio Europeo del Paisaje), o consiga ejercer seducción o tejer configuraciones entre personas, no preside la historia reciente. Una zarabanda de acontecimientos y transformaciones dificulta la estabilización, base de valores y significados. ¿Cómo dejarse seducir por un paisaje, cómo depositar afecto y trazar planes, que presuponen futuro, si en quince días puede verse convertido en un mar de plástico, o desfigurado por naves, surcado por zanjas, apresado por alambradas, colmatado de escombros? Al instalar algunos paisajes en el veloz azar, pulsados por transformaciones radicales, se impide que brote el apego y pierden continuidad y reconocimiento los posibles lazos cohesivos.

(B) La sobreabundancia espacial equivale para Augé a una desmesura en la movilidad y el acceso a imágenes y simulaciones, que nos instala en un permanente zum y un fulgurante "travelling", crea una falsa familiaridad con remotas facciones del planeta, nos expone a distorsiones crecientes en la apreciación de la diferencia y nos distrae como un cimbel o señuelo, alejándonos de las escalas ancestrales de percepción. Las imágenes circulan de un polo a otro, rebotando por el camino sobre lejanos satélites.

Algunos de estos efectos son muy perturbadores para la apreciación del paisaje. Una comarca turística puede verse jibarizada por una combinación de factores, entre ellos la prisa y el empaquetamiento para consumo, factores que reducen su riqueza a una colección de puntos donde se tiran fotos, o a unas rutas marcadas. El advenimiento de la televisión en los hogares y habitaciones de hotel vino a reducir la importancia de unas buenas vistas, de una ventana grata donde sentarse a leer. La pantalla televisiva vino a servir de ventana virtual. Este hecho, erosionador de un viejo puntal de la cultura paisajística, se ve ahora centuplicado por la proliferación de pantallas en tabletas, 
ordenadores y teléfonos móviles. En otro lugar he descrito este fenómeno como una creciente miopía para las escalas amplias; la atención, habituada a recibir incesantes cargas de información visual en el molde de distintas pantallas, se desentiende de la vaguedad, ambigüedad y parsimonia con que el mundo nos atiende cuando lo miramos directamente. Por otra parte, la tecnología de representación adquiere tal capacidad de filtrado que incluso paisajes gravemente degradados pueden aparecer favorecidos en la foto o el vídeo; este efecto, el de un entorno más tensionado, a veces desfigurado, pero que aparece prístino en la fotografía o filmación promocional, lo he denominado paradoja de la representación.

Parece casi una parábola de este exceso (B) la comparación entre dos ramas diferenciadas de la actual cartografía. Por un lado, la expresión del espacio, como mosaico jerarquizado, de rica diversidad interpretada, en los mapas Michelin (por ejemplo, la escala 1: 150000 de Francia), tan sabrosa en promesas y tentaciones de viaje que ha sido considerada una obra de arte en sí misma. Por otro lado, el inexpresivo continuo yermo de la cartografía de escala flexible Google. Ciertamente, sería una grave injusticia negar el formidable avance que supone esta última desde el punto de vista técnico. Pero el precio que pagar por la escala variable es la singular inexpresividad de los resultados, que parecen consagrar la total conversión de la superficie terrestre en una monda superficie homologada. La pura extensión desabrida, el arrasamiento de las singularidades, se convierten, metafóricamente, en el precio a pagar por la libertad de escala, la fulgurante movilidad de encuadre posibilitada por la técnica.

En una sugerente obra de ficción, La Carte et le Territoire, esta oposición es convertida en germen artístico, en el marco de una exposición titulada "La carte est plus intéressante que le territoire": "El contraste era llamativo: mientras que la foto de satélite no mostraba sino una sopa de verdes más o menos uniformes sembrada de vagas manchas azules, el mapa desplegaba un fascinante entrelazado de carreteras provinciales, rutas pintorescas, miradores, bosques, lagos y collados". ${ }^{20}$

20 "Le contraste était frappant: alors que la photo satellite ne laissait apparaître qu'une soupe de verts plus ou moins uniformes parsemée de vagues taches bleues, la carte développait un fascinant lacis de départementales, de routes pittoresques, de points de vue, de forêts, de lacs et de cols" (Houellebecq, 2010, p. 80). Sobre las profundas trazas que el ejercicio cartográfico imprime sobre la conceptualización y la ideología del espacio, es importante la magna aportación teórica de Farinelli; véase una panorámica en Lladó Mas (2013). 
(C) La individualización de las referencias permite a un ego floreciente establecer decorados e itinerarios personales construidos con libertad, bajo impulsos que se sitúan fuera de lo espacial. La pertenencia a comunidades virtuales crea una especie de deslocalización universal. Ante un espacio transitado por distintos itinerarios personales, crecientemente ocupado por biombos, aldeas de Potemkin y escenarios para ficciones paralelas, un espacio que regulado por innumerables partichelas de ejecución, se hace difícil encontrar una partitura común que armonice el conjunto. Enlaza todo ello con el concepto foucaultiano de la heterotopía, la imposibilidad de superponer tramas de relación: "vivimos en el seno de un conjunto de relaciones que definen ubicaciones mutuamente irreducibles y del todo imposibles de superponer" (Foucault, 1984, p. 47; véase en Dehaene \& De Cauter, 2008). ${ }^{21}$

No sorprende que la respuesta ante los cambios intensos, casi bursátiles, de algunos ruedos urbanos, áreas industriales y urbanizables, ocasione una especie de apatía paisajística. Al no tener garantía alguna de que se conserven los rasgos que hacen reconocible un paraje, se abandona su trato y cultivo espiritual; se da la espalda a aquel espacio, un proceso que o lo convierte en distal, o lo deja, si hay interés estratégico, en puertas de una operación de vaciamiento, previo al diseño total y control exhaustivo de circulaciones que lo convierte en nolugar.

\section{Conclusiones}

Los lugares se instalan en el mundo a través de lentos procesos de enraizamiento, que dejan sedimentar formas y lecturas, permitiendo la eclosión de un carácter, y por medio de densas dependencias y contigüidades, que los insertan en mallas y anidamientos espaciales. Ambos procesos, enraizamiento y constelación, se ven problematizados por la desmedida capacidad contemporánea de producir artificialidad. El no-lugar, en el sentido de Augé, parte de un inicial vaciamiento para instalar realidades dominadas por el diseño de la movilidad y las relaciones contractuales que la regulan.

En estas páginas se intenta reunir y reconciliar teorizaciones diversas sobre el lugar, como fundamento espacial de la vida social, y se busca encuadrar la polaridad lugar / no-lugar dentro de un marco más general, el de la teoría del paisaje. Para ello, se revisita una matriz

21 "nous vivons à l'intérieur d'un ensemble de relations qui définissent des emplacements irréductibles les uns aux autres et absolument non superposables" (Foucault, 2004, p. 14; véase en Dehaene \& De Cauter, 2008). 
clasificatoria de los paisajes, de elaboración propia, centrada en los afectos y las interacciones suscitadas en su seno. Paisajes distales son aquellos que ni despiertan afecto ni provocan interrelación personal. Se muestra que una lectura laxa de los no-lugares de Augé lleva a incluir entre ellos una serie de paisajes que en rigor son meramente distales. No-lugar y paisaje distal, lejos de ser sinónimos, son categorías complementarias. Ha de reconocerse en la vanguardia de transformación del paisaje la emergencia de un patrón dual: paisajes distales, alternando con nolugares. Este patrón sumerge bajo su ajedrez transformador las periferias urbanas, los bordes litorales y los entornos de grandes infraestructuras.

Se recorren asimismo los principales vectores de artificialidad, la sobremodernidad tal como la describe Augé, para hacer ver que sus efectos son inestabilizadores en grado sumo. No solo se vuelve problemática la fijación de ciertas piezas esenciales en la teorización sobre paisaje (poblaciones, carácter), sino que pierden nitidez los solapes y convergencias entre atributos y los propios intentos clasificatorios. En el límite, un metabolismo transformador llevado a sus últimas consecuencias crearía en coronas metropolitanas y filamentos urbanos una estructura proliferante basada en cápsulas de no-lugares rodeadas de un paisaje residual, de abandono y desinterés, es decir, distal.

La actual política del paisaje, y en particular la senda trazada por el Convenio Europeo del Paisaje, contiene invitaciones a la identificación, calificación, caracterización y fijación de objetivos de calidad. Todo ello reposa sobre una premisa, la de que los paisajes son reconocibles, están anclados y gozan de un grado de permanencia, sustentada en un carácter. Es prioritario entender en qué medida estos modelos de acción se ven problematizados por las potentes dinámicas de transformación, que llegan a suspender la premisa del anclaje -se vislumbra la posibilidad de nuevos paisajes de coordenadas cambiantes-. En tiempos de intensa volatilidad y derretimiento formal, teorizar sobre este delicado concepto, el carácter paisajístico, se convierte en tarea inaplazable.

Declaración responsable: El autor declara que no existe conflicto de intereses en relación con la publicación del presente artículo. 


\section{Bibliografía}

Altman, I., \& Low, S. M. (Eds.) (1992). Place Attachment. New York: Plenum Press.

Anderson, B., \& Harrison, P. (Eds.) (2010). Taking-place: Non-representational Theories and Geography. Farnham: Ashgate Publishing Limited.

Anyó Sayol, L. (2008). Identidad y videojuego: aplicación de la "Grid Group Cultural Theory" a la etnografía virtual. In E. Ardévol Piera, A. Estalella \& D. Domínguez Figaredo (Eds.), La mediación tecnológica en la práctica etnográfica (pp. 151-166). San Sebastián, Ankulegi: Antropologia Elkartea.

Arefi, M. (1999). Non-place and Placelessness as Narratives of Loss: Rethinking the Notion of Place. Journal of Urban Design, 4 (2), 179-193. https://doi.org/10.1080/1357480990872444 Augé, M. (1992). Non-lieux, introduction à une anthropologie de la surmodernité. Paris: La Librairie du XXe siècle, Seuil.

Augé, M. (2010). Retour sur les "non-lieux". Les transformations du paysage urbain. Le Seuil, Communications, 87, 171-178. https://doi.org/10.3917/commu.087.0171

Cacciari, M. (2002). Adolf Loos e il suo Angelo. Milan: Electa.

Canter, D. (1977). The Psychology of Place. London: Architectural Press.

Catling, J. (2003). W. G. Sebald's Landscapes of Memory. In R. Görner (Coord.), The Anatomist of Melancholy: Essays in Memory of W. G. Sebald (pp. 19-50). Múnich: Iudicium.

Certeau, M. de (1990). L'Invention du quotidien. Vol. I. Arts de faire. Paris: Gallimard.

Davallon, J. (2006). Le don du patrimoine: une approche communicationnelle de la patrimonialisation. Paris: Hermes Science-Lavoisier.

Dehaene, M., \& De Cauter, L. (Eds.) (2008). Heterotopia and the City. Public space in a postcivil society. London, New York: Routledge.

Demajo Meseguer, L. (2011). Barrios cerrados en ciudades latinoamericanas. URBS. Revista de Estudios Urbanos y Ciencias Sociales, 1(1), 151-160. Retrieved from http://www2.ual.es/urbs/index.php/urbs/article/view/demajo_meseguer

Dieterle, B. (2003). Ruines et chantiers de la mémoire. In Y. Clavaron, \& B. Dieterle (Eds.), La Mémoire des villes. The Memory of Cities (pp. 7-11). Université de Saint-Étienne.

Dostal, R. J. (2002). The Cambridge Companion to Gadamer. Cambridge University Press. 
Douglas, M. (2005). Grid and Group, New Developments. Workshop on Complexity and Cultural Theory in Honour of Michael Thompson, London School of Economics, June 2005. Retrieved from http://emk-complexity.s3.amazonaws.com/events/2005/MaryDouglas.pdf

Douglas, M. (2011). In the Active Voice. London: Routledge.

Escobar, A. (2001). Culture Sits in Places: Reflections on Globalism and Subaltern Strategies of Localization. Political Geography, 20(2), 139-174. https://doi.org/10.1016/S0962$\underline{6298(00) 00064-0}$

Foucault, M. (2004). Des espaces autres. Conférence au Cercle d'études architecturales, 14 mars 1967. Empan, 54, 12-19. https://doi.org/10.3917/empa.054.0012

Gallardo Frías, L. (2012). Lugar / No-lugar / Lugar en la arquitectura contemporánea (Doctoral dissertation, Universidad Politécnica de Madrid, Spain). Retrieved from http://oa.upm.es/10903/1/LAURA_GALLARDO_FRIAS.pdf

García Álvarez, J. (2009). Lugares, paisajes y políticas de memoria: una lectura geográfica. Boletín de la Asociación de Geógrafos Españoles, 51, 175-202. Retrieved from https://bage.age-geografia.es/ojs/index.php/bage/article/view/1137

García Martín, M. (2013). Percepciones y valoraciones sociales del territorio en las aglomeraciones urbanas: paisaje y lugar en el Aljarafe (Sevilla) (Doctoral dissertation, Universidad de Sevilla, Retrieved from https: / / dialnet.unirioja.es/servlet/tesis?codigo=192736

Gieryn, T. F. (2000). A Space for Place in Sociology. Annual Review of Sociology, 26, 463496. Retrieved from http://www.jstor.org/stable/223453

Gómez Zotano, J., \& Riesco Chueca, P. (2011). Marco conceptual y metodológico para los paisajes españoles. Aplicación a tres escalas espaciales. Sevilla: Consejería de Obras Públicas y Vivienda, Centro de Estudios Paisaje y Territorio, Ministerio de Medio Ambiente, Medio Rural y Marino.

Heise, U. (2008). Sense of Place and Sense of Planet: The Environmental Imagination of the Global. New York: Oxford UP.

Hetherington, K. (1997). The Badlands of Modernity. Heterotopia and Social Ordering. Londres, New York: Routledge.

Houellebecq, M. (2010). La Carte et le Territoire. París: Flammarion. 
Ipsen, D. (2006). Ort und Landschaff. Wiesbaden: Springer.

Jivén, G., \& Larkham, P. J. (2003). Sense of Place, Authenticity and Character: a Commentary. Journal of Urban Design, 8(1), 67-81. https://doi.org/10.1080/1357480032000064773

Kolb, D. (2008). Sprawling places. Georgia: University of Georgia Press.

Kundera, M. (2000). La ignorancia. Trad. B. de Moura. Barcelona: Tusquets.

Lazzari, M. (2012). The Role of Social Networking Services to Shape the Double Virtual Citizenship of Young Immigrants in Italy. In Proceedings of the IADIS International Conference on ICT, Society and Human Beings 2012. Lisbon, July 21-23, 2012. Retrieved from hitp://www. iadisportal.org/digital-library/

Le Bras, H. (1993). La planète au village: migrations et peuplement en France. Paris: DATAR.

Leach, N. (1998). The Dark Side of the Domus, The Journal of Architecture, 3(1), 3142. https://doi.org/10.1080/136023698374297

Lladó Mas, B. (2013). Franco Farinelli. Del mapa al laberinto, Barcelona: Icaria.

Long, J. J. (2007). W. G. Sebald - Image, Archive, Modernity. Edinburgh University Press.

Luna, A., \& Valverde, I. (2015). Teoría y paisaje II: Paisaje y emoción. El resurgir de las geografías emocionales. Barcelona: Universidad Pompeu Fabra.

Lynch, K. (1981). A Theory of Good City Form. Cambridge, MA: MIT Press.

Mamadouh, V. (1999). Grid-group Cultural Theory: an Introduction. GeoJournal, 47(3), 395409. https://doi.org/10.1023/A:1007024008646

Martínez Carneiro, X. L. (1997). Antela: a memoria asolagada. Vigo: Xerais.

Mendoza, C., \& Bartolo Ruiz, D. (2012). Lugar, sentido de lugar y procesos migratorios. Migración internacional desde la periferia de la Ciudad de México. Documents d'Anàlisi Geogràfica, 58(1), 51-77. https://doi.org/10.5565/rev/dag. 191

Mignon, Ch. (1982). Campos y campesinos de la Andalucía mediterránea. Ministerio de Agricultura, Pesca y Alimentación, Servicio de Publicaciones Agrarias.

Molinero, F., Ojeda, J. F., \& Tort, J. (Eds.) (2011). Los paisajes agrarios de España: caracterización, evolución y tipificación. Ministerio de Medio Ambiente y Medio Rural y Marino. 
Moore, J. D. (2004). The Social Basis of Sacred Spaces in the Prehispanic Andes: Ritual Landscapes of the Dead in Chimú and Inka societies. Journal of Archaeological Method and Theory, 17(1), 83-124. https://doi.org/10.1023/B:JARM.0000014348.86882.50

Muñoz, F. (2008). Urbanalización. Paisajes comunes, lugares globales. Barcelona: Gustavo Gili.

Nencini, F. (2005). I non luoghi. Milan: Silvana Editoriale.

Nogué, J. (Ed.) (2018). Yi-Fu Tuan. El arte de la geografía. Barcelona: Icaria Editorial.

Paasi, A. (1991). Deconstructing Regions: Notes on the Scales of Spatial Life. Environment and Planning A, 23 (2), 239-256. https://doi.org/10.1068/a230239

Paül i Carril, V. (2010). El cambio de los usos agrarios del suelo en el actual ámbito metropolitano de Barcelona (del siglo XVIII a la actualidad). Investigaciones geográficas, 53, 145-188. https://doi.org/10.14198/INGEO2010.53.07

Peillon, M., \& Corcoran, M. P. (2004). The Reconfiguration of Ireland. Dublin: IPA.

Punter, J. (1991). Participation in the Design of Urban Space, Landscape Design, 200, 24-27.

Relph, E. (1976). Place and Placelessness. Londres: Pion.

Sabatini, F., \& Salcedo, R. (2007). Gated Communities and the Poor in Santiago, Chile: Functional and Symbolic Integration in a Context of Aggressive Capitalist Colonization of Lowerclass Hreas. Housing Policy Debate, 18(3), 577606. https://doi.org/10.1080/10511482.2007.9521612

Riesco Chueca, P. (2003). Estéticas privadas y estéticas públicas en la producción y consumo del paisaje rural. In J. Fernández Lacomba, F. Roldán Castro \& F. Zoido Naranjo (Eds.), Territorio y patrimonio. Los paisajes andaluces (pp. 58-75). Granada: Instituto Andaluz de Patrimonio Histórico.

Riesco Chueca, P. (2011). La deliberación sobre el espacio vivido: Empirismo y comunicación en los paisajes postmodernos. In M. Almagro Jiménez (Ed.), Representaciones de la postmodernidad: una perspectiva interdisciplinar (pp. 69-113). Sevilla: ArCiBel Editores.

Schmitt, C. (1950). Der Nomos der Erde im Völkerrecht des Jus Publicum Europaeum. Berlin: Duncker \& Humblot.

Silva Pérez, R. (2011). El Poniente de Almería. El dinamismo y los conflictos de la agricultura bajo plástico. In F. Molinero, J. F. Ojeda \& J. Tort (Eds.), Los Paisajes Agrarios de España. 
Caracterización, Evolución y Tipificación (pp. 301-314). Ministerio de Medio Ambiente y Medio Rural y Marino.

Silva, R., \& Fernández, V., \& Molinero, F. (2016). El carácter del paisaje como medio para la identificación de los valores patrimoniales del viñedo español. In A. R. Ruiz, M. A. Serrano de la Cruz \& J. I. Plaza (Eds.), Treinta años de Política Agraria Común en España: Agricultura y multifuncionalidad en el contexto de la nueva ruralidad (pp. 900-915). Ciudad Real: Asociación de Geógrafos Españoles.

Smith, L. (2004). The Contested Landscape of Early Yellowstone. Journal of Cultural Geography, 22(1), 3-26. https://doi.org/10.1080/08873630409478245.

Spickard, J. V. (1989). A guide to Mary Douglas's three versions of grid/group theory. Sociological Analysis, 50(2), 151-170. Retrieved from https://www.jstor.org/stable/3710986

Tilley, Ch. (1994). A Phenomenology of Landscape. Places, Paths and Monuments. Oxford: Berg. Tuan, Y. (1977). Space and Place: The Perspective of Experience. Minneapolis: University of Minnesota Press.

Urry, J. (2007). Mobilities. Cambridge: Polity.

Venturi, R., Scott Brown, D., \& Izenour, S. (1972). Learning from Las Vegas. Cambridge MA: MIT Press.

Webber, M. M. (1964). The Urban Place and the Nonplace Urban Realm. In M.M. Webber, J.W. Dyckman, D.L. Foley et al., Explorations into Urban Structure (pp. 79-153). Philadelphia PA: University of Pennsylvania Press.

Zoido Naranjo, F. (2012). Paisaje urbano. Aportaciones para la definición de un marco teórico, conceptual y metodológico. In C. Delgado Viñas, J. Juaristi Linacero, \& S. Tomé Fernández (Eds.), Ciudades y paisajes urbanos en el siglo XXI (pp. 13-92). Santander: Librería Estudio. 